\title{
Tingkat Kepuasan Wisatawan Terhadap Kualitas Sarana dan Prasarana di Kawasan Kota Lama Semarang
}

Meike Lintang Puspitasari a,1, I Gede Anom Sastrawan a, 2

${ }^{1}$ meike.lintang@gmail.com, ${ }^{2}$ anom_sastrawan@unud.ac.id

a Program Studi Sarjana Destinasi Pariwisata, Fakultas Pariwisata, Universitas Udayana, Jl. Dr. R. Goris, Denpasar, Bali 80232 Indonesia

\section{Abstract}

This study aims to determine the level of tourist satisfaction with the quality of facilities and infrastructure in the Semarang Old City Area. Revitalization of the Semarang Old City Area is done by improving infrastructure and adding facilities and infrastructure. Good quality facilities and infrastructure can produce satisfaction for tourists who come. This research uses qualitative and quantitative data types, while the data sources used are primary and secondary sources. Data collection techniques used in this study were observation, questionnaires, and interviews. The measurement scale of variables uses the Likert scale. The technique of determining informants using purposive sampling. The data analysis technique used is quantitative descriptive. The results of this study are tourists most satisfied with pedestrian road and tourist most dissatisfied with bench and parking area. The condition of good facilities and infrastructure will produce satisfaction for tourists. The results of the analysis can be used as an evaluation for the manager of Semarang Old City Area.

Keyword: condition, quality, facilities, infrastructure, and satisfaction level.

\section{PENDAHULUAN}

Pemerintah daerah semakin gencar mengembangkan pariwisata yang berada di daerahnya, tak terkecuali Pemerintah Kota Semarang. Salah satu daya tarik wisata di Semarang yang telah mengalami pengembangan yaitu Kawasan Kota Lama Semarang yang selanjutnya disebut KKLS. KKLS telah mengalami revitalisasi. Revitalisasi tersebut bertujuan untuk mengejar gelar World Heritage UNESCO tahun 2020. Pasca revitalisasi, sarana dan prasarana di KKLS semakin lengkap dan tertata, sehingga wajah KKLS nampak indah. Wajah baru KKLS dengan kualitas sarana dan prasarana yang mengikuti, menarik semakin banyak wisatawan datang dan pastinya menimbulkan kepuasan tersendiri. Apalagi jika wisatawan tersebut pernah mengunjungi KKLS sebelum direvitalisasi. Diantara sarana dan prasana yang memuaskan pasti terdapat sarana dan prasarana yang kurang memuaskan atau diluar ekspektasi wisatawan. Ketidakpuasan wisatawan tersebut dapat dijadikan bahan evaluasi bagi pengelola untuk menyempurnakan kualitas sarana dan prasarana yang ada sehingga mampu menyeimbangkan ekspektasi wisatawan. Untuk itu diperlukan penelitian untuk mengukur tingkat kepuasan wisatawan terhadap sarana dan prasarana, khususnya di KKLS. Oleh karena itu, penelitian ini diberi judul "Tingkat Kepuasan Wisatawan Terhadap Kualitas Sarana dan Prasarana di Kawasan Kota Lama Semarang". Arti penting penelitian ini adalah untuk mengetahui tingkat kepuasan wisatawan terhadap kualitas sarana dan prasarana di Kawasan Kota Lama Semarang dalam mengejar gelar World Heritage UNESCO tahun 2020.

Penelitian terdahulu yang menjadi acuan dalam penelitian ini yaitu penelitian pertama yang dilakukan oleh Oktari Susetyarini dan Jussac Maulana pada tahun 2018 dengan judul "Pengukuran Tingkat Kepuasan Wisatawan Terhadap Fasilitas Umum, Sarana, Prasarana Umum, dan Fasilitas Pariwisata di Malioboro Pasca Revitalisasi Kawasan", penelitian kedua dilakukan oleh Nor Khasimah Aliman, Sharenna Mohamed Hashim, Siti Dalela Mohd Wahid, dan Syahmi Harudin pada tahun 2016 dengan judul "Tourist Satisfaction with Destination: An Investigation on Visitors to Langkawi Island", penelitian ketiga dilakukan oleh Munir Salleh, Khatijah Omar, Azizul Yadi Yaakop, dan Ahmad Ramli Mahmmod pada tahun 2013 dengan judul "Tourist Satisfaction in Malaysia", penelitian keempat dilakukan oleh Wahma Dewi Bintari dan Tri Yuningsih pada tahun 2017 dengan judul "Analisis Tentang Kepuasan Pengunjung di Taman Margasatwa Semarang", dan penelitian kelima dilakukan oleh Arnis Rochma Harani, Hermin Werdiningsih, dan Yasmina Nurul Falah pada tahun 2015 dengan judul "Kajian Keaktifan Kawasan Kota Lama Semarang Berdasarkan Aktifitas Pengguna".

Konsep yang digunakan sebagai acuan dalam penelitian ini meliputi konsep kepuasan, konsep wisatawan, konsep pariwisata, konsep daya tarik wisata, konsep komponen pariwisata, konsep 
heritage, konsep sarana, konsep prasarana, dan konsep kualitas.

\section{METODE PENELITIAN}

Penelitian ini dilakukan di Kawasan Kota Lama Semarang (KKLS). Lingkup permasalahan dalam peneliitian ini yaitu, yang pertama yaitu kondisi sarana dan prasarana di KKLS dengan aspek data: sarana pokok, sarana pelengkap, sarana penunjang, dan prasarana umum; dan lingkup permasalahan kedua yaitu tingkat kepuasan wisatawan terhadap kualitas fasilitas pariwisata di KKLS dengan aspek data: tingkat kepuasan terhadap sarana pokok, tingkat kepuasan terhadap sarana pelengkap, tingat kepuasan terhadap sarana penunjang, dan tingkat kepuasan terhadap prasarana umum. Jenis data yang digunakan dalam penelitian ini adalah data kuantitatif (Sugiyono, 2008) dan data kualitatif (Moleong, 2007). Penelitian ini bersumber pada sumber data primer dan sekunder (Moleong, 2007). Teknik pengumpulan data dalam penelitian ini menggunakan teknik observasi tidak berperanserta (Sugiyono, 2008:203), kuisioner online (Sugiyono, 2008:199), dan wawancara secara online (Adi, 2004:72). Penentuan informan dalam penelitian ini menggunakan teknik pusposive sampling (Arikunto, 2006). Teknik analisis data dalam penelitian ini menggunakan metode deskriptif kuantitatif (Bungin, 2007). Data dalam penelitian ini disajikan dalam bentuk tabel distribusi frekuensi. Penelitian ini menggunakan skala likert untuk membuat kuisioner.

\section{HASIL DAN PEMBAHASAN}

KKLS atau "The Little Netherland" berdiri sejak tahun 1678 sebagai upeti bagi kolonial Belanda oleh Amangkurat II karena berhasil memberantas pemberontakan Untung Suropati . Pada masa itu (abad ke 19-20), KKLS menjadi pusat perdagangan. Untuk kemanan warga serta wilayahnya, VOC lantas membangun benteng di kawasan tersebut dan menamainya Benteng Vijfhoek. Seiring berjalannya waktu, kawasan tersebut berkembang menjadi permukiman dan perkantoran. Tahun 1756 pembangunan benteng mengelilingi kawasan permukiman dan perkantoran (bersatu dengan benteng Vijfhoek) dilaksanakan. Namun, pada tahun 1824, gerbang dan menara pengawas benteng dirobohkan. Pada akhirnya, pasca proklamasi kemerdekaan, Indonesia mengambil alih kepemilikan KKLS. Karena tidak ada perkembangan dalam perekonomian dan perdagangan, satu-persatu pemilik bangunan di KKLS lantas meninggalkan Kawasan tersebut dengan membiarkan bangunannya kosong.

Berdasarkan pemanfaatan ruangnya, KKLS terbagi menjadi tiga fungsi kawasan, yaitu: fungsi hunian, fungsi perdagangan dan perkantoran, serta fungsi rekreasi dan budaya. Menurut RTBL (Rencana Tata Bangunan dan Lingkungan) KKLS yang ditetapkan dalam Peraturan Daerah Kota Semarang Nomor 8 tahun 2003, menyatakan bahwa KKLS merupakan warisan sejarah pertumbuhan Kota Semarang yang memiliki nilai arsitektural, estetis, ilmu pengetahuan dan budaya yang tinggi sehingga perlu dilestarikan dan ditata kembali secara terarah untuk menyesuaikan perkembangan zaman. Pengelola KKLS terdiri dari dua lembaga, yaitu Dinas Kebudayaan dan Pariwisata Kota Semarang dan Badan Pengelola Kawasan Kota Lama (BPK2L) Semarang. Dinas Kebudayaan dan Pariwisata Kota Semarang mengelola sarana dan prasarana, sedangkan BPK2L mengelola semua yang berkaitan dengan izin dan rekomendasi, seperti izin kegiatan dan izin pembangunan gedung. BPK2L memiliki wewenang untuk melaksanakan sebagian kewenangan konservasi dan revitalisasi.

Revitalisi KKLS tahun 2015 memperbaiki bangunan dan ruang publik, seperti: Gedung Spiegel, ruang publik Taman Garuda, ruang jalan di sekitar gedung Telkom, dan kantor perkebunan. Tahun 2017, dilakukan kembali revitalisasi yang biayanya mencapai 200 miliar rupiah. Tujuan dilakukan revitalisasi adalah untuk mengejar dadtar warisan budaya (world heritage) UNESCO pada tahun 2020. KKLS memiliki total luas lahan sebesar 31 hektar dengan sekitar 114 bangunan cagar budaya di dalamnya. Sebesar $80 \%$ bangunan adalah kepemilikan pribadi, sisanya milik BUMN. Gedung-gedung di dalam KKLS direvitalisai ringan sehingga tidak mengurangi keasliannya dan tetap berkarakter "Little Netherland". Tahun 2018, KKLS mendapat dana dari Kementrian Pekerjaan Umum dan Perumahan Rakyat (PUPR) untuk membangun infrastruktur.

KKLS memiliki berbagai fasilitas untuk memenuhi kebutuhan wisatawan yang datang. Adapun fasilitas tersebut meliputi restoran, café, sampai penginapan berupa hotel. Selain itu, di KKLS juga terdapat berbagai atraksi seperti diadakannya berbagai event, salah satu yang paling ramai adalah Festival Kota Lama yang diselenggarakan tiap tahunnya. Lokasi KKLS cukup strategis dengan akses yang mudah. Jarak KKLS dengan Stasiun Tawang hanya 750 meter atau jika melakukan perjalanan dengan kendaraan bermotor dapat ditempuh dalam waktu 3 menit. Sedangkan, jarak KKLS dengan Bandara

Internasional Ahmad Yani sebesar 8,5 kilometer atau jika melakukan perjalanan dengan kendaraan bermotor dapat ditempuh dalam waktu 17 menit. Di KKLS juga disediakan halte BRT (Bus Rapid Transit) Trans Semarang sehingga memudahkan 
wisatawan maupun pengunjung yang akan melakukan perjalanan ke KKLS secara efisien dan pastinya dengan budget rendah.

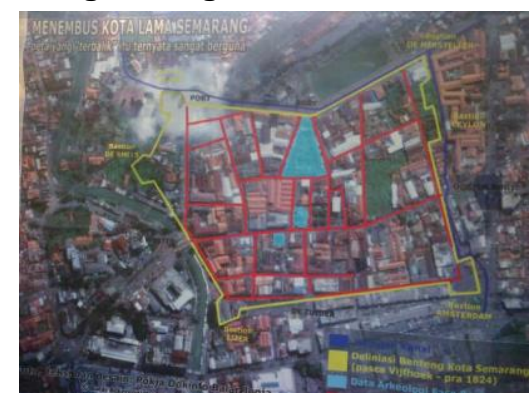

\section{Gambar 3.1 Kawasan Kota Lama Semarang \\ Sumber : www.jatengtoday.com}

Saat ini KKLS telah menyita perhatian orang banyak. Diperkirakan KKLS mampu menyerap 5,5 juta wisatawan tiap tahunnya. Nantinya, KKLS akan dibagi menjadi beberapa zona seperti zona city walk, zona satu mobil, dan zona lainnya. Pedestrian yang mengabiskan anggaran sebesar 200 miliar rupiah itu nampaknya dilakukan dengan hati-hati dengan menggunakan material batu alam demi terwujudnya World Heritage UNESCO 2020. Pemerintah Kota Semarang mengadakan uji coba program Car Free Night di KKLS. Setiap Hari Jumat dan Sabtu, pukul 18.0024.00 WIB, Jalan Cenderawasih dan Jalan Letjen Soeprapto hingga Jalan Mpu Tantular (Jembatan Mberok) akan ditutup aksesnya bagi kendaraan bermotor. Jika lancar, tahun ini Car Free Night akan diterapkan selama 24 jam.

Berdasarkan observasi, mayoritas wisatawan yang datang ke KKLS berjenis individual mass tourist dan psychocentic. Disebut berjenis individual mass tourist karena wisatawan memilih daerah tujuan wisata yang sudah terkenal dan perjalana tidak sepenuhnya diatur oleh travel angent. Mayoritas wisatawan memilih merencanakan perjalanannya sendiri dibanding menyewa guide. Disebut berjenis psychocentric karena wisatawan hanya mau mengunjungi daerah tujuan wisata yang memiliki fasilitas dengan standar yang memadai dan KKLS memiliki berbagai fasilitas yang memadai. Wisatawan di KKLS tidak bersifat petualang karena KKLS merupakan destinasi wisata kota yang cukup terkenal dan memiliki fasilitas yang memadai.

Berdasarkan penelitian, berikut adalah kondisi sarana dan prasarana di KKLS:

\section{a. Taman Sri Gunting}

Taman Sri Gunting terletak di samping Gereja Blenduk, Jalan Taman Sri Gunting. Jika KKLS dilihat secara keseluruhan, Taman Sri Gunting terlihat paling hijau dan rindang karena Taman
Sri Gunting dinaungi 3 pohon besar serta semak hias disekelilingnya. Ketika datang ke KKLS, wisatawan pasti melihat dan merasakan suasana Taman Sri Gunting. Hal yang dapat dirasakan di Taman Sri Gunting adalah suasana yang hijau, sejuk, dan bersih. Di dalam Taman Sri Gunting terdapat beberapa spot foto (sepeda dan becak yang dihias), keran air siap minum, tempat duduk, tempat sampah, akses free WiFi, serta informasi suhu udara dan kelembaban digital. Hal-hal tersebut menghasilkan respon wisatawan (responden) yang sebagian besar puas dan tidak ada yang tidak puas. Kondisi Taman Sri Gunting memberikan kepuasan bagi wisatawan yang datang.

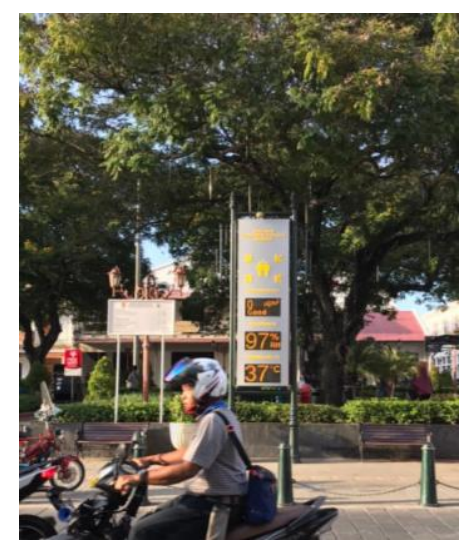

Gambar 3.2 Papan Digital di Taman Sri Gunting Sumber : Hasil Penelitian 2020

\section{b. Galeri Industri Kreatif Semarang}

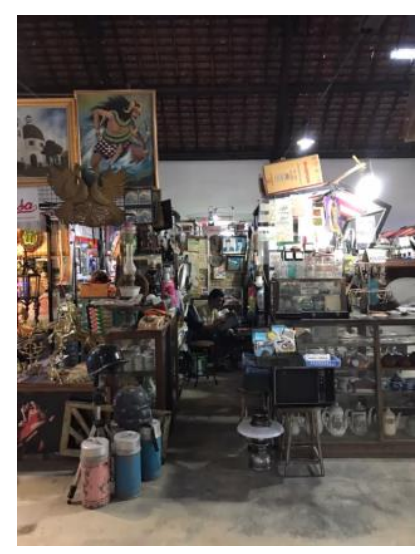

\section{Gambar 3.3 Kios Pedangan Barang Kuno di Galeri Industri Kreatif Sumber : Hasil Penelitian 2020}


Galeri Industri Kreatif Semarang terletak di Jalan Garuda nomor 1, belakang Gereja Blenduk. Gedung Galeri Industri Kreatif merupakan bekas gudang PT. PPI (Perusahaan Perdagangan Indonesia) yang selanjutnya di revitalisasi. Di dalam Gedung Galeri Industri Kreatif Semarang terdapat kios-kios pedagang yang menjual barang kuno seperti sepeda, alat elektronik, uang, lukisan, dan lain sebagainya; penjual pakaian (fashion); dan food court. Para pedangan barang kuno sangat ramah, bahkan mempersilahkan wisatawan yang hanya melihat-lihat saja atau mengambil foto saja. Ketika memasuki gedung, wisatawan sambut dengan kesan luas, rapi, dan bersih. Konsep Galeri Industri Kreatif Semarang adalah adanya wisata kuliner, oleh-oleh, dan fashion dalam satu lokasi. Wisatawan dapat menggunakan kartu untuk melakukan pembayaran di Galeri Industri Kreatif Semarang (pembayaran digital). Halhal tersebut bisa menjadi alasan mengapa sebagian besar wisatawan (responden) merasa puas dengan kondisi Galeri Industri Kreatif Semarang. Salah satu responden mengeluhkan penerangan yang kurang di dalam galeri. Kondisi penerangan yang kurang memungkinkan beberapa wisatawan merasa tidak puas.

\section{c. Food court}

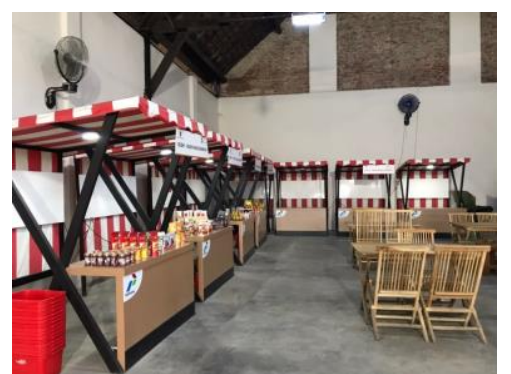

Gambar 3.4 Food Court KKLS

Sumber : Hasil Penelitian 2020

Food court KKLS terdapat di dalam Gedung Galeri Industri Kreatif Semarang. Terdapat dua bagian food court, yaitu stand oleh-oleh khas daerah dan stand makanan khas daerah. Kondisi food court bersih, sepi dengan luas ruangan cukup luas dan cukup sejuk karena ditempatkan beberapa kipas angin. Hal-hal tersebut yang membuat wisatawan merasa puas dengan kondisi food court KKLS. Walaupun food court sudah tersedia di KKLS, sebagian besar wisatawan belum pernah berkunjung. Hal ini dapat terjadi karena di sekitar KKLS banyak pedagang makanan dan minuman (pedangang kecil) dan café maupun resto, sehingga wisatawan lebih memilih untuk tidak berbelanja di food court. Selain itu, ada salah satu responden (wisatawan) megatakan bahwa food court sulit untuk ditemukan. Ada juga responden yang mengeluhkan stand food banyak yang tutup). Hal tersebut membuat beberapa wisatawan tidak puas dengan kondisi food court.

\section{d. Spot foto}

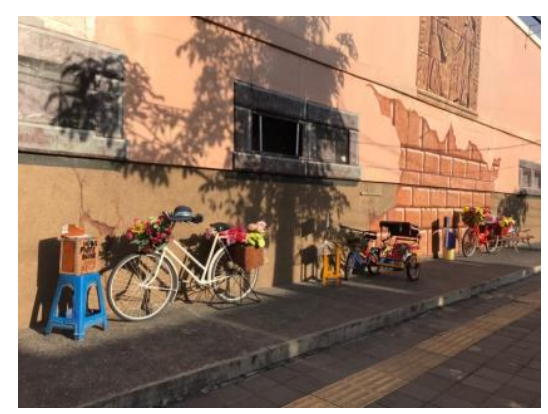

Gambar 3.5 Spot Foto Berupa Sepeda dan Becak

Sumber : Dokumentasi Pribadi

Spot foto yang dimaksud di sini adalah sepeda hias, becak hias, dan sepeda motor kuno yang dihias. Spot-spot terebut tersebar di KKLS, ada yang terdapat di Taman Sri Gunting, di samping Gereja Blenduk, di dekat Museum 3D, dan lain sebangainya. Sarana ini tidak dikelola oleh Dinas Pariwisata Kota Semarang maupun BPK2L, melainkan kepemilikan perorangan (masyarakat lokal). Di setiap spot foto diletakan kotak donasi. Jadi, setiap wisatawan yang mengambil foto di spot tersebut, diharapkan untuk memberikan donasi guna merawat spot tersebut. Kondisi spot foto nampak indah, unik, rapi, dan bersih. Hal tersebutlah memberikan kepuasan bagi sebagian wisatawan yang menggunakan spot foto.

\section{e. Toilet umum}

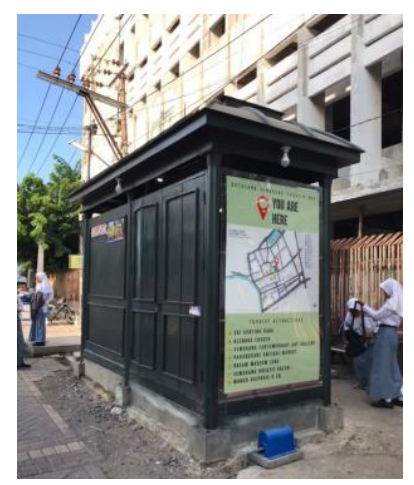

\section{Gambar 3.6 Toilet Umum di KKLS Sumber : Hasil Penelitian 2020}

KKLS memiliki satu toilet umum yang terletak di sekitar Taman Sri Gunting. Toilet umum KKLS berbentuk persegi panjang dan di sisi luar terdapat informasi atraksi wisata dengan master plan KKLS. Papan petunjuk lokasi toilet terletak di samping depan Taman Sri Gunting. 
Beberapa responden (wisatawan) mengeluhkan kurangnya kebersihan di toilet umum KKLS. Hal tersebut yang membuat beberapa wisatawan kurang puas dengan kondisi toilet umum.

\section{f. Keran air siap minum}

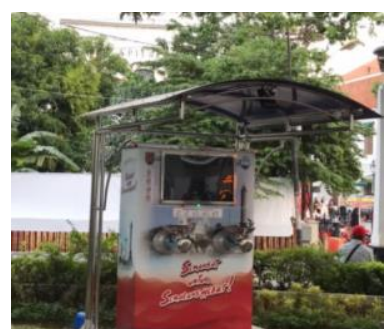

Gambar 3.7 Keran Air Siap Minum Sumber : Hasil Penelitian 2020

Keran air siap minum KKLS terletak di kawasan Taman Sri Gunting. Di dalam satu lokasi, terdapat 2 keran air siap minum. Tempat keran air siap minum cenderung bersih dan terdapat canopy yang melindungi keran tersebut sehingga tidak kepanasan dan meminimalisir terkena debu. Hal tersebut membuat beberapa wisatawan merasa puas dengan kondisikeran air siap minum di KKLS. Sebagian besar wisatawan belum pernah menggunakan keran air siap minum. Hal ini dapat terjadi karena lokasi keran air siap minum ada di dalam kawasan Taman Sri Gunting dan cenderung tertutup oleh rindangnya pohon (kurang strategis).

\section{g. Charger box}

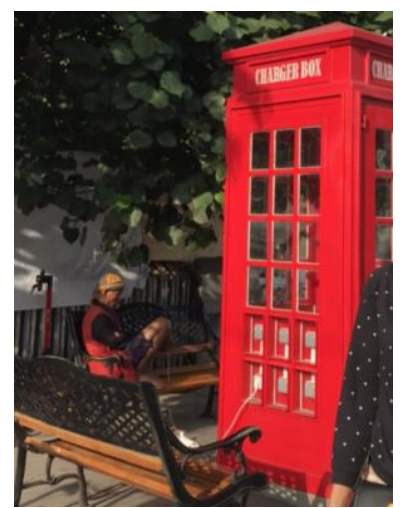

\section{Gambar 3.8 Charger Box di KKLS}

Sumber : Hasil Penelitian 2020

Kawasan Kota Lama Semarang memiliki dua charger box, yaitu di depan Museum 3D dan di dekat pos penyewaan sepeda. Charger box di KKLS merupakan street furniture yang memiliki fungsi untuk mengisi daya baterai telepon gengngam maupu kamera dan sebagai penghias ruang KKLS. Di sekitar charger box diberi bangku untuk wisatawan yang menunggu baterai telepon genggam maupun kamera terisi. Karena hal tersebut, sebagian wisatawan merasa puas dengan andanya charger box. Meskipun ada responden yang merasa tidak puas dengan kondisi charger box, mereka tidak mengemukakan hal apa yang membuat mereka tidak puas.

h. Bangku

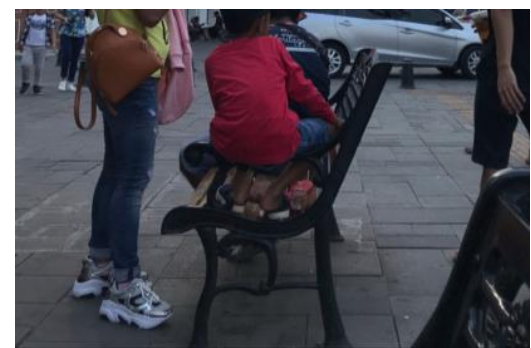

Gambar 3.9 Bangku di KKLS

Sumber : Hasil Penelitian 2020

Bangku yang tersebar di seluruh KKLS terbuat dari kayu dan baja. Bangku-bangku di KKLS termasuk ke dalam street furniture yang memiliki fugsi sebagai tempat bersistirahat (duduk) dan dapat mempercantik ruang KKLS. Kondisi bangku cukup baik, kuat, dan cukup bersih. Hal tersebut membuat sebagian besar wisatawan merasa puas dengan kondisi bangku yang ada. Selain itu, ada beberapa responden (wisatawan) mengatakan bahwa jumlah bangku kurang. Kurangnya jumlah bangku tersebut mempengarui respon wisatawan yang merasa tidak puas. Jika KKLS sedang kedatangan banyak pengunjung, biasanya bangku di KKLS penuh dan pengunjung yang ingin beristirahat cenderung menopangkan badannya di tembok yang ada. Selain itu, ada salah satu wisatawan yang memberi saran untuk lebih membersihkan bangku. Artinya, bangku di KKLS masih ada beberapa yang kurang bersih.

i. Tempat sampah

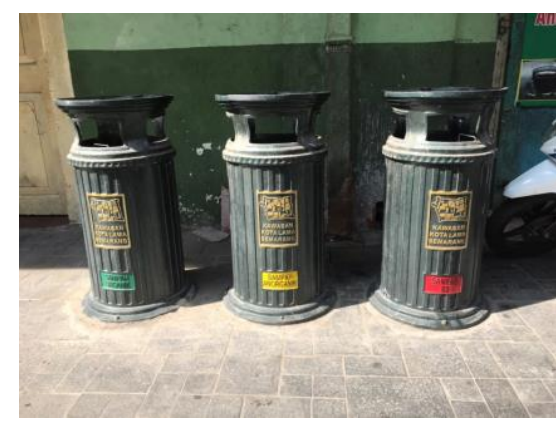

Gambar 3.10 Tempat Sampah di Jalan Pedestrian KKLS

Sumber : Hasil Penelitian 2020 
Tempat sampah di KKLS sudah dipisahkan antara sampah organik, anorganik, dan B3 atau Bahan Berbahaya dan Beracun. Hal tersebut dapat menjadi alasan sebagian besar responden (wisatawan) merasa puas dengan kondisi tempat sampah. Namun, ada beberapa responden yang mengeluhkan kurangnya tempat sampah yang tersebar sehingga masih banyak wisatawan maupun pedagang yang membuang sampah sembarang. Hal tersebut membuat wisatawan mejadi tidak puas dengan kondisi tempat sampah yang pada akhirnya menyebabkan ketidaknyamanan karena ada beberapa tempat yang kotor (akibat sampah dibuang sembarangan).

\section{j. Tempat parkir}

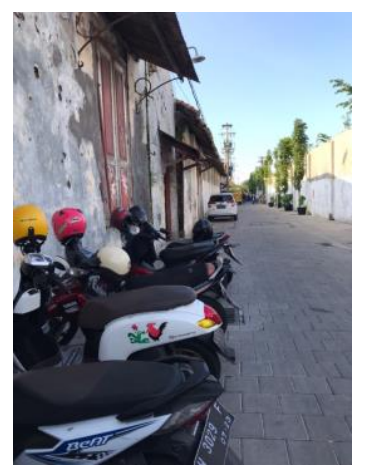

\section{Gambar 3.11 Salah Satu Tempat Parkir di KKLS \\ Sumber : Hasil Penelitian 2020}

Kawasan Kota Lama Semarang memiliki empat lahan parkir. Tempat parkir di KKLS bisa dibilang kurang ditata dan dikelola. Tempat parkir yang menyebar membuat beberapa wisatawan kebingungan menggunakan tempat parkir yang mana. Harga di tempat parkir sering berubah (mulai dari Rp 3.000,- sampai Rp 5.000,-Beberapa responden (wisatawan) mengeluhkan hal tersebut dan merasa kurang nyaman. Salah satu responen memberi komentar bahwa tempat parkir kurang nyaman karena matahari sangat terik. Ada juga yang memberi saran untuk memperbanyak tempat parkir dan membuat tempat parkir resmi. Mayoritas wisatawan belum pernah menggunakan tempat parkir. Hal tersebut dapat terjadi karena dibeberapa sudut KKLS telah dipasang titik antar-jemput ojek online. Wisatawan maupun pengunjung yang menggunakan ojek online tentunya tidak menggunakan tempat parkir.

\section{k. Penyewaan Sepeda dan Otoped}

Sarana penunjang di KKLS adalah penyewaan sepeda dan otoped melalui aplikasi Gowes. Wisatawan yang ingin menyewa sepeda maupun otoped di KKLS harus terlebih dahulu mengunduh aplikasi gowes di smartphone. Setelah diunduh, di di dalam aplikasi tersebut terdapat panduan bagaimana cara menyewa sepeda maupun otoped. Untuk menyewa sepeda, wisatawan membayar (top up) sebesar Rp 25.000,- dan untuk otoped wisatawan membayar sebesar Rp 10.000,-. Satu sepeda dapat digunakan selama 60 menit dan satu otoped hanya bisa digunakan 15 menit. Penyewaan ini dibuka mulai pukul 08.00 WIB 23.00 WIB. Hal tersebut membuat beberapa wisatawa merasa puas dengan penyewaan alat transportasi seperti ini. Sebagian besar wisatawan belum pernah menyewa sepeda dan otoped. Hal ini dapat terjadi karena tidak semua wisatawan suka dan memiliki aplikasi gowes.

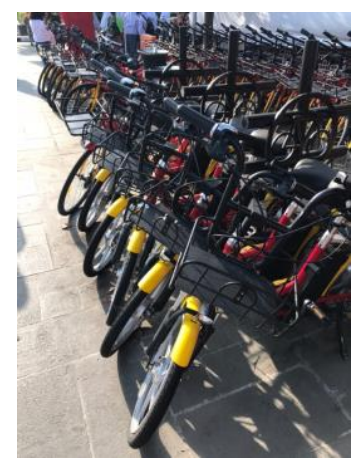

\section{Gambar 3.12 Sepeda dan Otoped yang Disewakan}

Sumber : Hasil Penelitian 2020

\section{Jalan pedestrian}

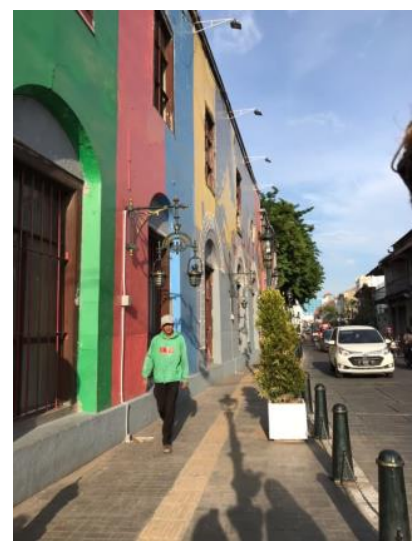

\section{Gambar 3.13 Jalan Pedestrian KKLS}

Sumber : Hasil Penelitian 2020

Hampir seluruh jalan di KKLS adalah jalan pedestrian. Jalan pedestrian di KKLS dilengkapi oleh jalur tuna netra. Di jalan pedestrian KKLS dilengkapi beberapa street furniture seperti lampu jalan, bangku, dan charger box yang menyerupai tempat telepon umum berwarna merah. Hal tersebut membuat sebagian besar wisatawan merasa puas terhadap kondisi jalan 
pedestrian. Namun, sebagian respondeng (wisatawan) mengeluhkan adanya sampah di beberapa sudut jalan. Artinya, jalan pedestrian KKLS kurang bersih dan hal tersebut membuat wisatawan kurang puas.

\section{m. Lampu jalan}

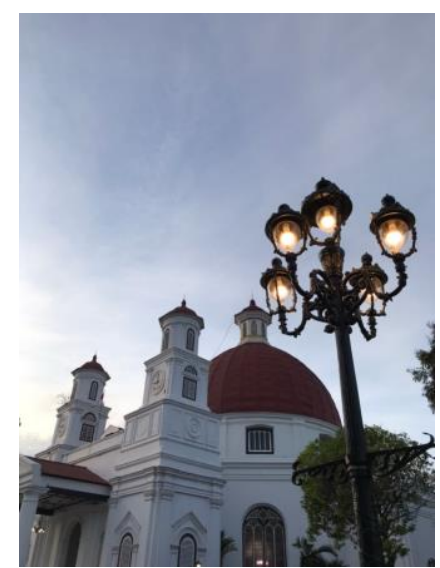

Gambar 3.14 Lampu Jalan di KKLS Sumber : Hasil Penelitian 2020

Lampu jalan di KKLS adalah street furniture yang memiliki fungsi untuk memberikan penerangan dan penghias ruang KKLS. Lampu jalan tersebut tersebar di hampir seluruh KKLS. Bentuknya yang unik dan lampu yang terang, membuat sebagian besar wisatawan merasa puas saat berkunjung ke KKLS pada malam hari. Namun, ada beberapa responden (wisatawan) yang mengeluhkan di beberapa jalan kecil penerangan lampu kurang. Ada salah satu wisatawan yang mengeluhkan penerangan kurang di depan Gereja Blenduk saat malam hari. Hal tersebut yang membuat wisatawan merasa tidak puas akan fungsi lampu jalan di KKLS.

n. WiFi

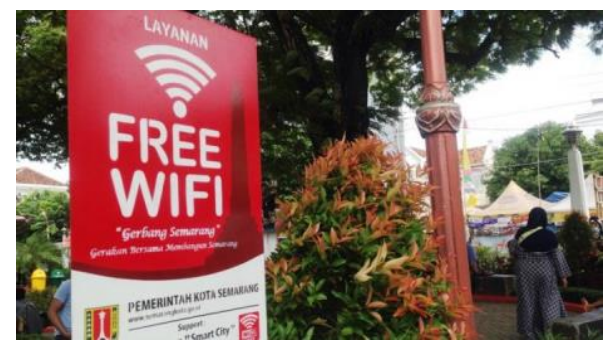

Gambar 3.15 Free WiFi di KKLS

(Taman Sri Gunting)

Sumber : www.jateng.tribunnews.com

Adanya layanan WiFi di KKLS yang bersifat gratis, membuat beberapa wisatawan merasa puas. Namun, ada beberapa responden (wisatawan) yang merasa tidak puas dan mengeluhkan mereka tidak tahu ada layanan WiFi. Ada juga wisatawan yang mengeluhkan koneksi internet cenderung lambat. Hal tersebut membuat beberapa responden merasa tidak puas dengan layanan WiFi yang ada.

Penelitian ini menggunakan skala likert untuk membuat kuisioner. Pada setiap jawaban akan diberi skor sebagai berikut:

\section{Tabel 3.1}

Skor Angket dengan Skala Likert

\begin{tabular}{|c|c|}
\hline Keterangan & Skor \\
\hline Sangat Puas & 5 \\
\hline Puas & 4 \\
\hline Netral & 3 \\
\hline Tidak Puas & 2 \\
\hline Sangat Tidak Puas & 1 \\
\hline
\end{tabular}

Hasil dari total skor kemudian dibandingkan dengan indeks penilaian sebagai berikut:

Tabel 3.2

Indeks Penilaian

\begin{tabular}{|c|c|}
\hline Indeks & Keterangan \\
\hline $0 \%-19,99 \%$ & Sangat Tidak Puas \\
\hline $20 \%-39,99 \%$ & Tidak Puas \\
\hline $40 \%-59,99 \%$ & Netral \\
\hline $60 \%-79,99 \%$ & Puas \\
\hline $80 \%-100 \%$ & Sangat Puas \\
\hline
\end{tabular}

Penelitian yang dilakukan memperoleh hasil sebagai berikut: 
Tabel 3.3

Kepuasan Wisatawan terhadap Kualitas Sarana dan Prasarana di KKLS

\begin{tabular}{|c|c|c|c|c|c|c|c|}
\hline No & $\begin{array}{c}\text { Sub } \\
\text { Variabel }\end{array}$ & 5 & 4 & 3 & 2 & 1 & $\mathbf{0}$ \\
\hline 1 & $\begin{array}{l}\text { Taman Sri } \\
\text { Gunting }\end{array}$ & 12 & 52 & 36 & 0 & 0 & 0 \\
\hline 2 & $\begin{array}{l}\text { Galeri } \\
\text { Industri } \\
\text { Kreatif } \\
\text { Semarang }\end{array}$ & 11 & 36 & 22 & 2 & 0 & 29 \\
\hline 3 & Food court & 2 & 28 & 20 & 3 & 1 & 46 \\
\hline 4 & Spot foto & 16 & 51 & 31 & 2 & 0 & 0 \\
\hline 5 & $\begin{array}{l}\text { Toilet } \\
\text { umum }\end{array}$ & 3 & 9 & 24 & 7 & 1 & 56 \\
\hline 6 & $\begin{array}{l}\text { Keran air } \\
\text { siap } \\
\text { minum }\end{array}$ & 3 & 10 & 20 & 4 & 1 & 62 \\
\hline 7 & $\begin{array}{l}\text { Charger } \\
\text { box }\end{array}$ & 3 & 26 & 12 & 1 & 1 & 57 \\
\hline 8 & Bangku & 13 & 46 & 28 & 11 & 2 & 0 \\
\hline 9 & $\begin{array}{l}\text { Tempat } \\
\text { sampah }\end{array}$ & 12 & 49 & 32 & 5 & 2 & 0 \\
\hline 10 & $\begin{array}{l}\text { Tempat } \\
\text { parkir }\end{array}$ & 2 & 9 & 29 & 7 & 4 & 49 \\
\hline 11 & $\begin{array}{l}\text { Penyewaan } \\
\text { sepeda dan } \\
\text { otoped }\end{array}$ & 3 & 16 & 15 & 3 & 0 & 63 \\
\hline 12 & $\begin{array}{l}\text { Jalan } \\
\text { pedestrian }\end{array}$ & 25 & 58 & 14 & 2 & 1 & 0 \\
\hline 13 & $\begin{array}{l}\text { Lampu } \\
\text { jalan }\end{array}$ & 24 & 49 & 17 & 6 & 0 & 4 \\
\hline 14 & WiFi & 4 & 9 & 29 & 7 & 2 & 49 \\
\hline & Total & 133 & 448 & 329 & 60 & 15 & 415 \\
\hline
\end{tabular}

Sumber: Hasil Penelitian 2020

$$
\begin{array}{ll}
\text { Jawaban Sangat Puas (SP) x skor } & =133 \times 5=665 \\
\text { Jawaban Puas (P) } \times \text { skor } & =448 \times 4=1792 \\
\text { Jawaban Netral (N) } \times \text { skor } & =329 \times 3=987 \\
\text { Jawaban Tidak Puas (TP) } \times \text { skor } & =60 \times 2=120 \\
\text { Jawaban Sangat Tidak Puas (STS) } & \text { skor }=15 \times 1=15 \\
\text { Total skor } & =\mathbf{3 5 7 9}
\end{array}
$$

Skor maksimum $=$ jumlah responden $\mathrm{x}$ skor tertinggi likert

Skor maksimum $=(133+448+329+60+15) \times 5$

\section{Skor maksimum $=4925$}

Indeks $(\%)=($ Total skor $:$ Skor maksimum $) \times 100$

Indeks $(\%)=(3579: 4925) \times 100$

Indeks $(\%)=0,726701 \times 100$

Indeks $(\%)=72,67 \%$

Nilai indeks yang didapatkan dari perhitungan tersebut adalah 72,67\%, maka dapat disimpulkan bahwa responden "puas" (nilai indeks 60\% - 79,99\%) dengan kualitas sarana dan prasarana di KKLS.

Sub variabel pada alternatif jawaban puas dan sangat puas yang paling tinggi adalah jalan pedestirian. Artinya, jalan pedestrian merupakan prasarana yang memiliki kualitas terbaik yang dapat memuaskan wisatawan. Sub variabel jawaban tidak puas paling tinggi adalah bangku. Artinya, bangku merupakan sarana yang kurang memiliki kualitas baik sehingga kurang dapat memberikan kepuasan kepada wisatawan. Sub variabel jawaban sangat tidak puas paling tinggi adalah tempat parkir. Artinya, tempat parkir merupakan sarana yang memiliki kualitas kurang baik sehingga kurang memberikan kepuasan kepada wisatawan.

\section{SIMPULAN DAN SARAN}

\subsection{Simpulan}

Berdasarkan hasil dan pembahasan, dapat disimpulkan bahwa kondisi sarana dan prasarana di KKLS mempengaruhi kepuasan yang dirasakan wisatawan. Sarana dan prasarana yang memiliki kondisi baik (kualitas baik) memberikan kepuasan kepada wisatawan. Tingkat kepuasan wisatawan terhadap kualitas sarana dan prasarana di KKLS diperoleh dari hasil kuisioner dengan 4 variabel utama yaitu sarana pokok, sarana pelengkap, sarana penunjang, dan prasarana umum. Hasil kuisioner menjelaskan bahwa wisatawan paling puas dengan prasarana jalan pedestrian, hal tersebut berbanding lurus dengan kondisi jalan pedestrian KKLS yang tertata, indah, dan lengkap. Jalan pedestrian di KKLS dilengkapi oleh jalur tuna netra. Di jalan pedestrian KKLS dilengkapi beberapa street furniture seperti lampu jalan, bangku, dan charger box. Sarana yang mendapat hasil tidak puas dari wisatawan adalah bangku dan tempat parkir. Hal tersebut berbanding lurus dengan kondisi bangku di KKLS yang kurang jumlahnya dan kurang kebersihannya, serta tempat parkir yang masih belum memiliki sistem yang jelas sehingga banyak wisatawan yang tidak nyaman. Hasil kuisioner secara keseluruhan menjelaskan bahwa sebagian besar wisatawan puas dengan kualitas sarana dan prasarana di KKLS dengan nilai indeks yang didapatkan sebesar $72,67 \%$.

\subsection{Saran}

Berdasarkan simpulan diatas, adapun saran yang diberikan kepada pengelola agar dapat meningkatkan kualitas sarana dan prasarana di KKLS yaitu memperbaiki sarana tempat parkir. Dari hasil kuisioner, wisatawan kurang mendapat kepuasan dari tempat parkir. Hal ini terjadi karena menurut beberapa wisatawan, tempat parkir di 
KKLS kurang tertata, harga berubah-ubah, dan terdapat parkir liar. Diharapkan, pengelola dapat memperbaiki sistem tempat parkir di KKLS. Selain tempat parkir, wisatawan juga mengeluhkan bangku yang kotor, jalan kecil yang kurang peneranan, toilet yang kurang bersih, trotoar rusak, WiFi yang kurang kuat dan luas, dan lain-

\section{DAFTAR PUSTAKA/REFERENSI}

Adi, Rianto. 2004. Metodologi Penelitian Sosial dan Hukum. Jakarta: Granit.

Aliman, N. K., Hashim, S. M., Wahid, S. D. M., \& Harudin, S. (2016). Tourist Satisfaction with a Destination: An Investigation on Visitors to Langkawi Island. International Journal of Marketing Studies, 8(3), 173188.

Analisa, F.C.K. (2018). Dampak Revitalisasi Terhadap Aktivitas Vandalisme di Kawasan Kota Lama Semarang. Jurnal Arsitektur, 12(2), 97-103.

Ardiwidjaja, Roby. 2018. Arkeowisata: Mengembangkan Daya Tarik Pelestarian Warisan Budaya. Yogyakarta: Deepublish.

Ardiwidjaja, Roby. 2019. Pariwisata Budaya: Pelestarian Budaya Sebagai Daya Tarik Ke-Indonesiaan. Sidoarjo: Uwais Inspirasi Indonesia.

Arikunto. 2006. Prosedur Penelitian Suatu Pendekatan Praktek. Jakarta: PT. Rineka Cipta.

Bintari, W. D., \& Yuniningsih, T. (2017). Analisis Tentang Kepuasan Pengunjung di Taman Margasatwa Semarang. Journal of Public Policy and Management Review, 6(3), 183-197.

Bungin, Burhan. 2007. Penelitian Kualitatif: Komunikasi, Ekonomi, Kebijakan Publik dan Ilmu Sosial lainnya.Jakarta:Putra Grafika

Grahadwiswara, A., Hidayat, Z., \& Nurcahyanto, H. (2014). Pengelolaan Kawasan Kota Lama Semarang Sebagai Salah Satu Kawasan Pariwisata di Kota Semarang. Journal of Public Policy and Management Review, 3(4), 66-75.

Harani, A. R., Werdiningsih, H., \& Falah, Y. N. (2015). Kajian Keaktifan Kawasan Kota Lama Semarang berdasarkan Aktivitas Pengguna. Modul, 15(2), 157-163.

Hermawan, Asep. 2005. Penelitian Bisnis Paradigma Kuantitatif. Jakarta: Grasindo.

Kristiana, Yustisia. 2019. Buku Ajar Studi Ekowisata. Yogyakarta: Deepublish.

Maryati \& Suryawati. 2007. Sosiologi untuk SMA dan MA Kelas XII. Jakarta: Erlangga.

Moleong, Lexy J. 2007. Metodologi Penelitian Kualitatif, Bandung: PT. Remaja Rosdakarya Offset.

Murvianti, S. D., \& Arida, I. N. S. (2015). Potensi Pantai Perancak Sebagai Daya Tarik Wisata Desa Tibuneneng Kuta Utara Badung. Jurnal Destinasi Pariwisata, 3(2), 51-57

Nurdiani, N. (2014). Teknik sampling snowball dalam penelitian lapangan. ComTech: Computer, Mathematics and Engineering Applications, 5(2), 1110-1118.

Pinata \& Diarta. 2009. Pengantar Ilmu Pariwisata. Yogyakarta: ANDI.

Salleh, M., Omar, K., Yaakop, A. Y., \& Mahmmod, A. R. (2013) Tourist Satisfaction in Malaysia. International Journal of Bussiness and Social Science, 4(5).

Sari, Y., \& Purwantiasning, A. W. (2018). Analisis Pemanfaatan Kembali Bangunan Cagar Budaya Toko Merah Kota Tua Jakarta. Jurnal Architecture Innovation, 2(2).

Sugiyono. 2008. Metode Penelitian Kuantitatif Kualitatif dan R\&D. Bandung: ALFABETA.

Susetyarini, 0., \& Masjhoer, J. M. (2018). Pengukuran Tingkat Kepuasan Wisatawan Terhadap Fasilitas Umum, Prasarana Umum, dan Fasilitas Pariwisata di Malionoro lain. Kiranya pengelola lebih memperhatikan sarana dan prasarana tersebut. Karena ada beberapa wisatawan yang mengeluhkan kurangnya bangku untuk beristirahat, maka sebaiknya pengelola segera memikirkan untuk menambah tempat beristirahat agar wisatawan yang berekreasi tidak kelelahan.

Pascarevitalisasi Kawasan. Jurnal Kepariwisataan 12(1), 41-54.

Suwena \& Widiatmaja. 2017. Pengetahuan Dasar Ilmu Kepariwisataan. Denpasar: Pustaka Larasan.

Wulanningrum, S. D. (2014). Elemen-elemen Pembentuk Kota yang Berpengaruh terhadap Citra Kota (Studi Kasus: Kota Lama Semarang). Jurnal Pembangunan Wilayah \& Kota, 10(2), 197-204.

Sumber Lain:

Adelia, Like. "Kini Jalan-jalan di Kota Lama Semarang Bisa Naik Sepeda dan Otoped, Simak Cara Sewanya". Diakses dari www.jateng.tribunnews.com pada tanggal 21 April 2020.

Mughis, Abdul. "Begini Peta Situs Benteng Dalam Tanah Kota Lama". Diakses dari www.jatengtoday.com, pada tangga 2 November 2020.

Rudi. "Kota Lama Semarang, Kapsul Waktu di Tengah Kota Semarang". Diakses dari www.nativeindonesia.com, pada tanggal 19 Februari 2020.

Safuan, Akhmad. "Revitalisasi Kota Lama Semarang Kejar Word Heritage UNESCO". Diakes dari www.mediaindonesia.com, pada tanggal 19 Februari 2020.

Senjaya, Immanuel. "Revitalisasi Lanjutan Kota Lama Semarang Dimulai September". Diakses dar www.antaranews.com, pada tanggal 6 Februari 2020.

Tim Penyusun. "Revitalisasi Tahap 1 Kelar, Wajah Baru Kota Lama Semarang Mulai Nampak". Diakses dari www.semarang.kompas.com, pada tanggal 6 Februari 2020 . 